\title{
EFFECT OF DIFFERENT IRRIGATION REGIMES AND ZEOLITE APPLICATION ON YIELD AND QUALITY OF SILAGE CORN HYBRIDS
}

\author{
Fereshteh Seif ${ }^{1}$, Farzad Paknejad $^{1, *}$, Farhad Azizi $^{2}$, Ali Kashani ${ }^{1}$ and Mehdi Shahabifar ${ }^{3}$
}

\author{
${ }^{1}$ Department of Agronomy, Karaj Branch, Islamic Azad University, Karaj, Iran \\ ${ }^{2}$ Seed and Plant Improvement Institute, Agricultural Research, Education \& Extension Organization (AREEO),Karaj, Iran \\ ${ }^{3}$ Soil and Water Research Institute, Agricultural Research, Education \& Extension Organization (AREEO),Karaj, Iran
}

Received - June 18, 2016; Revision - November 06, 2016; Accepted - December 16, 2016

Available Online - December 29, 2016

DOI: http://dx.doi.org/10.18006/2016.4(VIS).721.729

KEYWORDS
Limited irrigation
Zeolite
Fodder production
Forage quality
Corn

\begin{abstract}
Present study was carried out to evaluate the effects of irrigation regimes and zeolite on the yield and quality parameters of silage corn hybrids. Study was conducted at Seed and Plant Improvement Institute in Karaj, Iran during 2013. The experiment was arranged in a three-replicated split-spilt plot based on randomized complete blocks design (RCBD) including three irrigation regimes as main plots (irrigation after 70, 100 and $130 \mathrm{~mm}$ evaporation from standard class A evaporation pan), two levels of zeolite as sub plots (0, 10 ton/ha) and three hybrids of silage corn (KSC704, KSC705 and KSC720) as sub subplot. Results of this study indicated that increasing water stress from optimum irrigation ( $\operatorname{Ir}_{70}$ ) to moderate $\left(\operatorname{Ir}_{100}\right)$ and low irrigation $\left(\operatorname{Ir}_{130}\right)$ caused 25 and 37\% reduction in forage dry matter yield but no significant difference was reported in protein yield. Moreover, application of zeolite have significant effect on forage yield and also have significant effect on protein yield $(\mathrm{P}<0.01)$. Forage quality parameters including water soluble carbohydrates, crude protein, acid detergent fiber and neutral detergent fiber increased and dry matter digestibility reduced when there was limited irrigation imposition. Among the tested corn seed hybrids KSC704 hybrid produced the highest dry forage yield and in terms of protein yield, no significant difference was reported between KSC720. KSC705 hybrid had the lowest acid detergent fiber and neutral detergent fiber and the highest dry matter digestibility.
\end{abstract}

* Corresponding author

E-mail: farzadpaknejad@yahoo.com (Farzad Paknejad)

Peer review under responsibility of Journal of Experimental Biology and Agricultural Sciences.

Production and Hosting by Horizon Publisher India [HPI] (http://www.horizonpublisherindia.in/).

All rights reserved.
All the article published by Journal of Experimental Biology and Agricultural Sciences is licensed under a Creative Commons Attribution-NonCommercial 4.0 International License Based on a work at www.jebas.org.

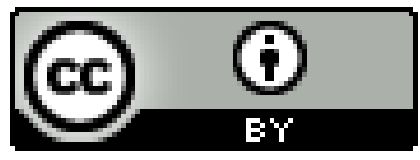




\section{Introduction}

In present scenario drought became a worldwide problem and most of the applied researches are based on the drought resistance sustainable crop production (Kojić et al., 2012). Demand of water for irrigation continuously increasing while a drastic reduction was reported in the availability of water, condition became more critical under arid and semi-arid environmental conditions (Rostamza et al., 2011). Alternative forage sources which can grow under these extreme conditions could be utilized to cope with the declining water availability (Marsalis \& Bean, 2010). Approximately, seventy three (73) percent of Iranian agricultural production area has arid and semi-arid climatic conditions (Abarghouei et al., 2011). Therefore, effective alternative management strategies are required for the efficient uses of water. Among the available information, retaining soil moisture and preventing substantial loss of water by the use of zeolite was used by researchers (Mumpton, 1999; Armandpisheh et al., 2009; Ahmed et al., 2010). Zeolites are hydrated aluminosilicates of alkaline with open three-dimensional structure and are able to lose or gain water reversibly and exchange extra framework cations, both without crystal structure changes (Mumpton, 1999). Zeolites can act as water moderators and can absorb up to $55 \%$ water of their own weight, later on this water released slowly as per plant water demand (Pisarovic et al., 2003).

Further, Ahmed et al. (2010) and Polat et al. (2004) also reported that Zeolites can enhance the better utilization of NPK nutrition and play an important role in the plant growth. Krutilina et al. (2000) also reported a significant effect of zeolite on the improvement of biomass production and rate of photosynthesis in maize and barley crops. Similarly, Keshavarz \& Farahbakhsh, (2012) reported that under the drought conditions application of zeolite increased the yield of millet crop. Also, similar type of improvement was reported in rapeseed (Valadabadi et al., 2010) and Lathyrus sativus (Pirzad \& Mohammadzade, 2014)

Forage crops play an important role in supplying energy and protein to livestock (Eskandari et al., 2009). In breeding of forage crops, increase of yield and forage quality are the main factors which play prominent role in the introduction of new varieties. Forages with good quality should have high dry matter yield, energy, digestibility and low fiber for optimal fermentation in the silo and storage. Silage corn have almost all these features, except the high protein content and this phenomenon make it better than other forage plants (Curran \& Posch, 1999). Various researchers reported the scarcity of irrigation water may cause reduction in dry matter yield of forage crops (Vasilakoglou et al., 2011; Keshavarz \& Farahbakhsh, 2012; Jahanzad et al., 2013). Knowledge about the influence of drought on nutritive quality of forage plants is inconsistent and limited. Some studied like Jahanzad et al. (2013) reported that drought condition may cause reduction in NDF and ADF concentration while it can improve the concentration of CP, DMD, WSC and DMD in forage sorghum cultivars. Similar type of findings was reported by Newman (2014) under drought stress conditions. Further, Xu \&Lascano (2007) reported that drought stress reduced the silo quality.

Compared to well-watered treatments, the silage produced from drought stressed plants had higher $\mathrm{CP}, \mathrm{ADF}, \mathrm{NDF}$, lignin contents and lower total digestible nutrients and starch. Limited informations are available with concern to the integrated effects of irrigation and application of zeolite on yield and forage quality of silage corn. KSC704 is currently the most common hybrid of silage corn in Iran. However, newly released hybrids, KSC720 and KSC705, have been also introduced to eliminate the probable problems concerning with a single corn planting in the country. The objective of this study was to determine the effect of zeolite on yield and quality of three silage corn hybrids (KSC704, KSC705 and KSC720) under normal and stress conditions.

\section{Materials and Methods}

The experiment was conducted at the experimental field of Seed and Plant Improvement Institute, Karaj, Iran $\left(35^{\circ} 47^{`} \mathrm{~N}\right.$, $50^{\circ} 55^{\prime} \mathrm{W}$, altitude $1254.5 \mathrm{~m}$ ) during 2013 . Study area has an average of 150-160 dry days in a year and coming in the hot and dry Mediterranean climate zones. The experiment was arranged in spilt-spilt-plot with three replicates by following randomized complete blocks (RCBD) design. Three irrigation regimes including $\operatorname{Ir}_{70}$ (optimum irrigation -irrigation when evaporation reached $70 \mathrm{~mm}$, using evaporation pan class "A"), $\operatorname{Ir}_{100}$ (moderate) and $\operatorname{Ir}_{130}$ (low irrigation) were used as main plots. While, two levels of zeolite $(0,10$ ton/ha) were used as sub- plots and also three hybrids of silage corn (KSC704, KSC705 and KSC720) were considered as sub-sub-plots.

The experiments were carried out in a clay-loam soil. Important physical and chemical properties of soil based on soil test results are presented in Table 1 and on the basis of these results dose of fertilizers application were determined. To determine the physical and chemical properties of soil at experimental field, 15 soil samples were randomly collected from 0-30 and 30-60 cm depth. Samples were carefully mixed together and turned into a single sample and were transferred to the laboratory. Physicochemical properties of the collected soil samples were determined by method described by Hesse (1971) and have been shown in Table 1. Distance between rows and plants per row were considered 75 and $15.5 \mathrm{~cm}$, respectively $\left(85000\right.$ plants. ha $\left.^{-1}\right)$. Each sub sub-plot included 4 rows with spacing of $0.75 \mathrm{~m}$ and length of $6 \mathrm{~m}$. Irrigation regimes were applied when plants were completely established with 6 to 8 leaves, by average. Plots were irrigated when evaporation reached the considered amount for each irrigation regimes $(70,100$, and $130 \mathrm{~mm}$ evaporation from the surface of the class A evaporation pan). In order to determine the water volume for irrigation, a soil sample was collected from each plot in depth of root development region before irrigation. 
Table 1 Selected properties of the soil at the experimental site.

\begin{tabular}{|lcccccccccccc|}
$\begin{array}{l}\text { Soil depth } \\
(\mathbf{c m})\end{array}$ & $\begin{array}{c}\text { Total } \mathbf{N} \\
(\boldsymbol{\%})\end{array}$ & $\begin{array}{c}\mathbf{P} \\
(\mathbf{m g} / \mathbf{k g})\end{array}$ & $\begin{array}{c}\mathbf{K} \\
(\mathbf{m g} / \mathbf{k g})\end{array}$ & $\begin{array}{c}\text { OC } \\
(\boldsymbol{\%})\end{array}$ & $\mathbf{P H}$ & $\begin{array}{c}\text { EC } \\
(\mathbf{d s} / \mathbf{m})\end{array}$ & $\boldsymbol{\rho b}$ & $\begin{array}{c}\text { F.C } \\
(\boldsymbol{\%})\end{array}$ & $\begin{array}{c}\text { Clay } \\
(\boldsymbol{\%})\end{array}$ & $\begin{array}{c}\text { Silt } \\
(\boldsymbol{\%})\end{array}$ & $\begin{array}{c}\text { Sand } \\
(\boldsymbol{\%})\end{array}$ & $\begin{array}{c}\text { Soil } \\
\text { texture }\end{array}$ \\
\hline $\mathbf{0 - 3 0}$ & 0.08 & 10.4 & 380 & 0.80 & 7.4 & 1.20 & 1.39 & 26.7 & 31 & 36 & 33 & $\begin{array}{c}\text { Clay } \\
\text { loam }\end{array}$ \\
\hline $\mathbf{3 0 - 6 0}$ & 0.06 & 9.2 & 334 & 0.64 & 7.5 & 1.60 & 1.42 & 28.1 & - & - & - & - \\
\hline
\end{tabular}

OC: organic carbon, F.C: field capacity, $\rho_{\mathrm{b}}$ : soil bulk density

The samples were kept in $80^{\circ} \mathrm{C}$ oven for 24 hours. The weight of soil moisture content was determined by the method given by Azizi \& Mahrokh, 2012 where moisture content was calculated by using equations 1 and the volume of water needed for irrigation was determined by using equations 2 and 3.

Moisture content in soil $(\Theta m)=$ wet soil weight $(\mathrm{gr})$ - dry soil weight (gr)/ dry soil weight(gr) ..............1

$\mathrm{H}=\rho \mathrm{b}(\Theta \mathrm{F} . \mathrm{C}-\Theta \mathrm{\Theta m}) \mathrm{D} \ldots \ldots \ldots \ldots \ldots \ldots \ldots . \ldots . \ldots \ldots$

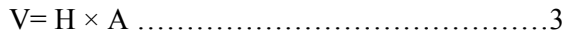

Where $\mathrm{H}$ is water height in the plot; $\rho$ b is soil bulk density; OF.C is the moisture level at field capacity; $\mathrm{Om}$ is plot moisture at irrigation time; $\mathrm{D}$ is the root development depth in different growth stages and $\mathrm{V}$ is the irrigation water volume needed for each plot and $\mathrm{A}$ is the plot area $\left(18 \mathrm{~m}^{2}\right)$.

10 plants were randomly selected from each plot to determine dry forage yield. Then, the samples were dried in an oven at $70^{\circ} \mathrm{C}$ for $72 \mathrm{~h}$, and dry matter yield per unit area was measured. Forage quality parameters was measured including crude protein (CP), water soluble carbohydrate (WSC), acid detergent fiber (ADF), neutral detergent fiber (NDF), dry matter digestibility (DMD) and ASH. Near infrared reflectance spectroscopy (NIRS) method described by Jafari et al (2003) was used for quality analysis. Dried samples were ground through the $0.1 \mathrm{~mm}$ screen of a cyclone mill and scanned using a near-infrared reflectance spectroscopy (NIRS, Informatics Perten 8600 Feed Analyzer) at wavelengths ranging from 500 to $2400 \mathrm{~nm}$. Protein yield was calculated by multiplying dry matter yield to crude protein content and all values are given in $\%$ on dry matter basis. Data were analyzed using the analysis of variance (ANOVA) and general linear model (GLM) procedures of SAS (SAS Institute, 2003). Effects were considered significant at P-values $\leq 0.05$ in the F-test. Duncan multiple range test was conducted for comparison of means.

\section{Results and Discussion}

\subsection{Forage dry matter}

Dry matter yield was significantly affected $(\mathrm{P}<0.01)$ by different irrigation regimes (Table 2), among various tested irrigation regimes, highest dry matter yield (15939 kg. ha $\left.{ }^{-1}\right)$ was obtained from normal irrigation regime $\left(\operatorname{Ir}_{70}\right)$ while the lowest dry forage yield $\left(10036 \mathrm{~kg}\right.$. ha $\left.{ }^{-1}\right)$ was observed at low irrigation level $\left(\operatorname{Ir}_{130}\right)$. Irrigation regime, $\operatorname{Ir}_{70}$ has shorter irrigation intervals than $\operatorname{Ir}_{100}$ and $\operatorname{Ir}_{130}$ and it produced 25 and $37 \%$ higher forage dry matter than the rest two, respectively. Kramer \& Boyer (1995) suggested that when soil water ratio is not enough to facilitate nutrient uptake by roots, plants face difficulty in absorbing essential elements such as nitrogen and phosphorus for their normal growth which caused reduction in final yield. This statement justified the results obtained in present study. Further, various researchers reported that impaired mitosis, cell elongation and expansion result reduced plant height, leaf area and crop growth under drought stress (Nonami, 1998; Kaya et al., 2006; Hussain et al., 2008).

Now, in these days it is well established that reduced dry matter yield of forage is associated with drought stress (Marsalis et al., 2009; Marsalis \& Bean, 2010; Rostamza et al., 2011; Jahanzad et al., 2013). Result of this study suggested that use of zeolite increased dry forage yield ( $\mathrm{P}<0.01)$ by $20 \%$ from $11202 \mathrm{~kg}$. ha ${ }^{-1}$ to $14106 \mathrm{~kg}$. ha ${ }^{-1}$ (Table 3). According to Torkashvand \& Shadparvar (2013) application of zeolite could be beneficial with respect to increased water holding capacity of soil. Similarly, Ahmed et al. (2010) suggested that zeolite application not only increase the uptake of N,P,K but also increase the efficiency of their use by plants. Valadabadi et al. (2010) reported significant improvement in the yield of rapeseed by the application of Zeolite under drought stress. Similar type of improvement was reported by Najafinezhad et al. (2014) in corn crop. These results are in accordance with the findings of present study. While Turk et al. (2006) reported contradictory results when they tested the effect of Zeolite on the yield of Alfalfa crops. Corn hybrids also differed significantly $(\mathrm{P}<0.01)$ in terms of forage dry matter (Table 2$)$ and corn hybrid KSC704 produced the highest dry forage yield (14330 kg. ha-1) and contained 10 and 25\% higher forage dry matter than KSC720 and KSC705, respectively (Table 3). Interaction between various treatments has no significant effect on dry forage yield.

\subsection{Forage quality}

\subsubsection{Crude protein}

Crude protein content which is one of the most important factors in forage quality (Wang \& Frei, 2011) has been significantly affected $(\mathrm{P}<0.01)$ by irrigation levels, zeolite application and corn cultivars (Table 2). In present study it was reported that less irrigation led to a progressive rise in $\mathrm{CP}$ content. 
Table 2 Analysis of variance of silage corn hybrids traits under irrigation treatments and zeolite.

\begin{tabular}{|lcccccccc|} 
S.O.V & df & $\begin{array}{c}\text { Yield } \\
\left(\mathbf{k g ~ h a}^{-1}\right)\end{array}$ & $\begin{array}{c}\text { WSC } \\
(\%)\end{array}$ & $\begin{array}{c}\text { CP } \\
(\%)\end{array}$ & $\begin{array}{c}\text { Protein yield } \\
(\mathbf{k g ~ h a})\end{array}$ & $\begin{array}{c}\text { ADF } \\
(\%)\end{array}$ & $\begin{array}{c}\text { NDF } \\
(\%)\end{array}$ & $\begin{array}{c}\text { DMD } \\
(\%)\end{array}$ \\
\hline Replication & 2 & $53744014^{*}$ & $0.675^{\mathrm{ns}}$ & $0.208^{\mathrm{ns}}$ & $380159^{*}$ & $8.81^{\mathrm{ns}}$ & $14.28^{\mathrm{ns}}$ & $3.58^{\mathrm{ns}}$ \\
\hline Irrigation & 2 & $162850877^{* *}$ & $120.21^{* *}$ & $41.35^{* *}$ & $65994^{\mathrm{ns}}$ & $249.85^{* *}$ & $586.58^{*}$ & $402.3^{* *}$ \\
\hline E(a) & 4 & 3833548 & 3.025 & 0.410 & 36997 & 11.75 & 51.19 & 3.61 \\
\hline Zeolite & 1 & $113822281^{* *}$ & $17.17^{\mathrm{ns}}$ & $15.01^{* *}$ & $245522^{* *}$ & $10.15^{\mathrm{ns}}$ & $187.60^{\mathrm{ns}}$ & $14.23^{\mathrm{ns}}$ \\
\hline Irrigation* zeolite & 2 & $319077^{\mathrm{ns}}$ & $8.229^{\mathrm{ns}}$ & $2.51^{*}$ & $18114^{\mathrm{ns}}$ & $20.54^{\mathrm{ns}}$ & $30.82^{\mathrm{ns}}$ & $6.49^{\mathrm{ns}}$ \\
\hline E(b) & 6 & 490398 & 6.36 & 0.372 & 7628 & 6.25 & 37.39 & 6.33 \\
\hline Hybrid & 2 & $58719385^{* *}$ & $85.05^{* *}$ & $11.64^{* *}$ & $918926^{* *}$ & $23.95^{*}$ & $82.18^{* *}$ & $120.0^{* *}$ \\
\hline Irrigation* Hybrid & 4 & $597206^{\mathrm{ns}}$ & $6.95^{* *}$ & $0.473^{\mathrm{ns}}$ & $17387^{\mathrm{ns}}$ & $13.29^{\mathrm{ns}}$ & $35.34^{*}$ & $9.25^{\mathrm{ns}}$ \\
\hline Zeolite* Hybrid & 2 & $447291^{\mathrm{ns}}$ & $4.05^{\mathrm{ns}}$ & $0.0222^{\mathrm{ns}}$ & $5483^{\mathrm{ns}}$ & $0.28^{\mathrm{ns}}$ & $12.51^{\mathrm{ns}}$ & $6.92^{\mathrm{ns}}$ \\
\hline Irrigation*Zeolite* Hybrid & 4 & $752988^{\mathrm{ns}}$ & $2.67^{\mathrm{ns}}$ & $0.132^{\mathrm{ns}}$ & $4403^{\mathrm{ns}}$ & $4.93^{\mathrm{ns}}$ & $10.81^{\mathrm{ns}}$ & $6.54^{\mathrm{ns}}$ \\
\hline E(c) & 24 & 2797962 & 1.403 & 0.215 & 30937 & 5.56 & 10.90 & 4.49 \\
\hline C.V & - & 13.21 & 4.35 & 5.37 & 16.59 & 9.10 & 7.44 & 3.17 \\
\hline
\end{tabular}

ns - Non significant, $*$ and $* *$ significant at $\mathrm{P}<0.05$ and $\mathrm{P}<0.01$, respectively.

Various researchers reported that water deficit intensifies forage $\mathrm{CP}$ content as a result of nitrogen accumulation (Pessarakli et al., 2005; Haberle et al., 2008) and accumulation of protein metabolites such as proline in leaves (Pelleschi et al., 1997). Further, the negative effects of drought stress on dry matter accumulation have been suggested by many researchers as a main factor related to higher protein concentrations (Gooding et al., 2003; Asseng \& Milroy, 2006; Weightman et al., 2008).

These results are in agreement with the findings of this study. However, Dwivedi et al. (1996) have reported lower protein concentration under drought stress. Significant interactions between irrigation levels and zeolite application were also reported in this study $(\mathrm{P}<0.05)$. Zeolite reduced the negative effect of drought stress in mild $\left(\operatorname{Ir}_{100}\right)$ and severe stress $\left(\operatorname{Ir}_{130}\right)$ condition and increase the crude protein content but this improvement in crude protein content are not significantly differ that the normal irrigation condition $\left(\operatorname{Ir}_{70}\right)$ (Table 4). Huang \& Petrovic(1994) suggested that zeolite can improve the water retention capacity of the soil and decreased severity of drought stress, in this manner findings of this study are in agreement with these researchers. The hybrids also had significant differences $(\mathrm{P}<0.01)$ in crude protein content (Table 1). At corn hybrid level, highest $\mathrm{CP}$ content (9.4\%) was observed in KSC720 hybrid (Table 3).

\subsubsection{Protein yield}

Protein yield combines the total biomass produced and forage $\mathrm{CP}$ content. Unlike $\mathrm{CP}$, protein yield showed no significant difference as intervals of irrigation increased, it could be explained by higher forage dry matter yield and lower protein content at $\operatorname{Ir}_{70}$ compared with $\operatorname{Ir}_{100}$ and $\operatorname{Ir}_{130}$ irrigation regimes (Table 3).

Table 3 Effect of irrigation regime, zeolite and hybrid on yield and quality traits of silage corn.

\begin{tabular}{|c|c|c|c|c|c|c|c|c|}
\hline Forage quality parameters & & $\begin{array}{c}\text { Yield } \\
\left(\mathrm{kg} \mathrm{ha}^{-1}\right)\end{array}$ & $\begin{array}{l}\text { WSC } \\
(\%)\end{array}$ & $\begin{array}{l}\text { CP } \\
(\%)\end{array}$ & $\begin{array}{l}\text { Protein yield } \\
\left(\mathrm{kg} \mathrm{ha}^{-1}\right)\end{array}$ & NDF (\%) & ADF (\%) & $\begin{array}{c}\text { DMD } \\
(\%)\end{array}$ \\
\hline \multirow[t]{3}{*}{ Irrigation regime } & $\mathrm{Ir}_{70}$ & $15939^{a}$ & $24.8^{\mathrm{c}}$ & $7.0^{\mathrm{c}}$ & $1120^{\mathrm{a}}$ & $39.8^{\mathrm{b}}$ & $22.1^{\mathrm{c}}$ & $71.3^{\mathrm{a}}$ \\
\hline & $\mathrm{Ir}_{100}$ & $11986^{\mathrm{b}}$ & $26.9^{\mathrm{b}}$ & $8.9^{\mathrm{b}}$ & $1062^{\mathrm{a}}$ & $42.4^{\mathrm{b}}$ & $26.0^{\mathrm{b}}$ & $66.7^{b}$ \\
\hline & $\mathrm{Ir}_{130}$ & $10036^{\mathrm{c}}$ & $29.9^{\mathrm{a}}$ & $10.0^{\mathrm{a}}$ & $999^{\mathrm{a}}$ & $50.7^{\mathrm{a}}$ & $29.5^{\mathrm{a}}$ & $61.9^{\mathrm{c}}$ \\
\hline L.S. & & $* *$ & $* *$ & $* *$ & ns & $*$ & $* *$ & $* *$ \\
\hline \multirow[t]{2}{*}{ Zeolite } & $\mathrm{Z}_{0}$ & $11202^{\mathrm{b}}$ & $27.8^{\mathrm{a}}$ & $9.1^{\mathrm{a}}$ & $993^{\mathrm{b}}$ & $42.5^{\mathrm{a}}$ & $25.4^{\mathrm{a}}$ & $67.1^{\mathrm{a}}$ \\
\hline & $\mathrm{Z}_{1}$ & $14330^{\mathrm{a}}$ & $26.7^{\mathrm{a}}$ & $8.1^{\mathrm{b}}$ & $1128^{\mathrm{a}}$ & $46.2^{\mathrm{a}}$ & $26.3^{\mathrm{a}}$ & $66.1^{\mathrm{a}}$ \\
\hline \multirow[t]{2}{*}{ L.S. } & & $* *$ & ns & $* *$ & $* *$ & Ns & ns & ns \\
\hline & KSC704 & $14330^{\mathrm{a}}$ & $29.3^{\mathrm{a}}$ & $8.7^{\mathrm{b}}$ & $1216^{\mathrm{a}}$ & $45.0^{\mathrm{a}}$ & $26.7^{\mathrm{a}}$ & $65.7^{\mathrm{b}}$ \\
\hline \multirow[t]{2}{*}{ hybrid } & KSC705 & $10741^{\mathrm{c}}$ & $25.0^{\mathrm{c}}$ & $7.8^{\mathrm{c}}$ & $801^{\mathrm{b}}$ & $41.9^{\mathrm{b}}$ & $24.6^{\mathrm{b}}$ & $69.5^{\mathrm{a}}$ \\
\hline & KSC720 & $12891^{\mathrm{b}}$ & $27.4^{\mathrm{b}}$ & $9.4^{\mathrm{a}}$ & $1164^{\mathrm{a}}$ & $46.1^{\mathrm{a}}$ & $26.4^{\mathrm{a}}$ & $64.6^{\mathrm{b}}$ \\
\hline L.S & & $* *$ & $* *$ & $* *$ & $* *$ & $* *$ & $*$ & $* *$ \\
\hline
\end{tabular}

Means in the same column followed by letters differ significantly at $\mathrm{P}<0.05 ; \mathrm{Ir}_{70}, \mathrm{Ir}_{100}$, and $\mathrm{Ir}_{130}$ represent high, moderate, and low irrigation levels; $\mathrm{Z}_{0}$ and $\mathrm{Z}_{1}$ represent consumption 0 and 10 ton per hectare, respectively; L.S.: level of significance; * $\mathrm{P}<0.05$; ** $\mathrm{P}<$ 0.01 ; Non-significant (ns) effect of interaction. 
Table 4 Effects of irrigation regime and zeolite interaction on yield and quality traits of silage corn.

\begin{tabular}{|c|c|c|c|c|c|c|c|c|}
\hline Irrigation regime & Zeolite & $\begin{array}{c}\text { Yield (kg ha } \\
\left.\mathbf{1}_{\mathbf{1}}\right)\end{array}$ & $\begin{array}{l}\mathrm{CP} \\
(\%)\end{array}$ & $\begin{array}{c}\text { Protein yield (kg } \\
\text { ha }^{-1} \text { ) }\end{array}$ & $\begin{array}{l}\text { WSC } \\
(\%)\end{array}$ & DMD (\%) & $\begin{array}{l}\text { NDF } \\
(\%)\end{array}$ & $\operatorname{ADF}(\%)$ \\
\hline \multirow[t]{2}{*}{$\mathbf{I r}_{70}$} & $\mathrm{Z}_{0}$ & $14640^{\mathrm{b}}$ & $7.1^{\mathrm{d}}$ & $1052^{\mathrm{b}}$ & $25.4^{\mathrm{bc}}$ & $71.7^{\mathrm{a}}$ & $39.1^{\mathrm{c}}$ & $20.4^{\mathrm{c}}$ \\
\hline & $\mathrm{Z}_{1}$ & $17238^{\mathrm{a}}$ & $6.8^{\mathrm{d}}$ & $1187^{\mathrm{a}}$ & $24.2^{\mathrm{b}}$ & $71.0^{\mathrm{a}}$ & $40.5^{\mathrm{bc}}$ & $23.8^{\mathrm{b}}$ \\
\hline \multirow[t]{2}{*}{$\mathbf{I r}_{100}$} & $\mathrm{Z}_{0}$ & $10442^{\mathrm{e}}$ & $9.8^{\mathrm{b}}$ & $1026^{\mathrm{b}}$ & $28.2^{\mathrm{ab}}$ & $66.7^{\mathrm{b}}$ & $40.8^{\mathrm{bc}}$ & $26.2^{\mathrm{b}}$ \\
\hline & $\mathrm{Z}_{1}$ & $13530^{\mathrm{c}}$ & $8.0^{\mathrm{c}}$ & $1098^{\mathrm{ab}}$ & $25.7^{\mathrm{bc}}$ & $66.8^{\mathrm{b}}$ & $44.1^{\mathrm{bc}}$ & $25.9^{\mathrm{b}}$ \\
\hline \multirow[t]{2}{*}{$\mathbf{I r}_{130}$} & $\mathrm{Z}_{0}$ & $8523^{\mathrm{f}}$ & $10.5^{\mathrm{a}}$ & $899^{\mathrm{c}}$ & $29.8^{\mathrm{a}}$ & $63.0^{\mathrm{c}}$ & $47.5^{\mathrm{ab}}$ & $29.7^{\mathrm{a}}$ \\
\hline & $\mathrm{Z}_{1}$ & $11548^{\mathrm{d}}$ & $9.5^{\mathrm{b}}$ & $1098^{\mathrm{ab}}$ & $30.1^{\mathrm{a}}$ & $60.7^{\mathrm{c}}$ & $54.0^{\mathrm{ab}}$ & $29.3^{\mathrm{a}}$ \\
\hline L.S. & & ns & $*$ & ns & ns & $\mathrm{ns}$ & ns & $\mathrm{ns}$ \\
\hline
\end{tabular}

Means in the same column followed by letters differ significantly at $\mathrm{P}<0.05 ; \mathrm{Ir}_{70}, \mathrm{Ir}_{100}$, and $\mathrm{Ir}_{130}$ represent high, moderate, and low irrigation levels; $\mathrm{Z}_{0}$ and $\mathrm{Z}_{1}$ represent consumption 0 and 10 ton per hectare, respectively; L.S.: level of significance; * $\mathrm{P}<0.05$; ** $\mathrm{P}<$ 0.01 ; Non-significant (ns) effect of interaction.

Similar types of findings was reported by Jahanzad et al (2013) and Asay et al (2002), these researchers reported that drought stress reduced dry matter yield and increased protein content in sorghum forage and tall fescue, respectively. However in their study the reduction amount of dry matter was very high and finally the protein yield reduced significantly when limited irrigation was imposed. Although zeolite did not have any significant effect on crude protein content, here also application of zeolite caused some increases in protein yield ( $\mathrm{P}$ $<0.01$ ) but also did not show any significant difference (Table 2). Similar, type of findings was Najafinezhad et al. (2014) and Nasri et al. (2012) reported by using zeolite, these researchers find some increase in protein yield of maize and sorghum. Hybrids had significant differences in crude protein content $(\mathrm{P}$ $<0.01)$ and KSC720 shows superiority in terms of protein yield on KSC704 and KSC705 (Table 3).

\subsubsection{Water-soluble carbohydrates}

Water soluble carbohydrates represent the most important source of energy in the finished diet (Coleman \& Moore, 2003) and have positive influence on fodder intake and are important for an efficient utilization of dietary N (Küchenmeister et al., 2013). WSC content was significantly $(\mathrm{P}<0.01)$ affected by irrigation levels and cultivars as shown in Table 2 . In this experiment, less irrigation led to a progressive rise in WSC content (Table 3). Significant increases in WSC content under drought stress may be because of osmotic adjustments of plants (DaCosta \& Huang, 2006; Nakayama et al., 2007), reduction in starch formation (Bethke et al., 2009) and due to the inhibition in the activity of the enzyme starch synthase which resulting in impeded conversion of sugars to starch (Wang \& Frei, 2011).

According to Buxton (1996) rate of photosynthesisis usually less affected by drought as compared to the rate of respiration and growth and this may be a possible reason of increasing digestible soluble sugars in plants. Hybrids had significant difference $(\mathrm{P}<0.01)$ on WSC content (Table 2). Among three hybrids, highest WSC content was observed in KSC704 hybrid (Table 3). Also, WSC content was influenced $(\mathrm{P}<0.01)$ by the interaction of irrigation regime and hybrid (Table 2).

Table 5 Effects of irrigation regime and hybrid interaction on yield and quality traits of silage corn.

\begin{tabular}{|c|c|c|c|c|c|c|c|c|}
\hline Irrigation regime & Hybrid & $\begin{array}{l}\text { Yield (kg } \\
\text { ha }^{-1} \text { ) }\end{array}$ & $\mathbf{C P}(\%)$ & $\begin{array}{l}\text { Protein yield } \\
\left(\mathrm{kg} \mathrm{ha}^{-1}\right)\end{array}$ & $\begin{array}{l}\text { WSC } \\
(\%)\end{array}$ & NDF (\%) & $\begin{array}{l}\text { ADF } \\
(\%)\end{array}$ & DMD (\%) \\
\hline \multirow[t]{3}{*}{$\mathbf{I r}_{70}$} & KSC 704 & $17740^{\mathrm{a}}$ & $7.2^{\mathrm{e}}$ & $1274^{\mathrm{a}}$ & $27.3^{\mathrm{d}}$ & $40.6^{\mathrm{de}}$ & $22.2^{\mathrm{ef}}$ & $71.7^{\mathrm{ab}}$ \\
\hline & KSC705 & $13828^{\mathrm{b}}$ & $6.3^{\mathrm{f}}$ & $873^{\mathrm{cd}}$ & $22.6^{\mathrm{f}}$ & $36.8^{\mathrm{e}}$ & $20.2^{\mathrm{f}}$ & $73.2^{\mathrm{a}}$ \\
\hline & KSC720 & $16249^{\mathrm{a}}$ & $7.5^{\mathrm{de}}$ & $1212^{\mathrm{ab}}$ & $24.5^{\mathrm{e}}$ & $42.0^{\text {cd }}$ & $23.8^{\mathrm{de}}$ & $69.1^{\mathrm{c}}$ \\
\hline \multirow[t]{3}{*}{$\mathbf{I r}_{100}$} & KSC 704 & $13445^{\mathrm{bc}}$ & $8.8^{\mathrm{c}}$ & $1183^{\mathrm{ab}}$ & $29.3^{\mathrm{bc}}$ & $45.7^{\mathrm{bc}}$ & $26.3^{\mathrm{cd}}$ & $65.4^{\mathrm{d}}$ \\
\hline & KSC705 & $10007^{\mathrm{de}}$ & $7.9^{\mathrm{d}}$ & $771^{\mathrm{d}}$ & $23.5^{\mathrm{ef}}$ & $39.3^{\mathrm{de}}$ & $26.3^{\mathrm{cd}}$ & $69.3^{\mathrm{bc}}$ \\
\hline & KSC720 & $12507^{\mathrm{bc}}$ & $10.0^{\mathrm{b}}$ & $1232^{\mathrm{ab}}$ & $28.0^{\mathrm{cd}}$ & $42.2^{\mathrm{cd}}$ & $25.5^{\mathrm{cd}}$ & $65.4^{\mathrm{d}}$ \\
\hline \multirow[t]{3}{*}{$\mathbf{I r}_{130}$} & KSC 704 & $11804^{\mathrm{cd}}$ & $10.1^{\mathrm{ab}}$ & $1189^{\mathrm{ab}}$ & $31.4^{\mathrm{a}}$ & $48.6^{\mathrm{b}}$ & $31.6^{\mathrm{a}}$ & $60.1^{\mathrm{e}}$ \\
\hline & KSC705 & $8387^{\mathrm{e}}$ & $9.2^{\mathrm{c}}$ & $759^{\mathrm{d}}$ & $28.8^{\mathrm{bc}}$ & $49.7^{\mathrm{b}}$ & $27.2^{\mathrm{bc}}$ & $66.1^{\mathrm{d}}$ \\
\hline & KSC720 & $9916^{\text {de }}$ & $10.6^{\mathrm{a}}$ & $1047^{\mathrm{bc}}$ & $29.6^{\mathrm{b}}$ & $54.0^{\mathrm{a}}$ & $29.8^{\mathrm{ab}}$ & $59.4^{\mathrm{e}}$ \\
\hline L.S. & & ns & ns & ns & $* *$ & $*$ & ns & $\mathrm{Ns}$ \\
\hline
\end{tabular}

Means in the same column followed by letters differ significantly at $\mathrm{P}<0.05$; $\mathrm{Ir}_{70}, \mathrm{Ir}_{100}$, and $\mathrm{Ir}_{130}$ represent high, moderate, and low irrigation levels; $\mathrm{Z}_{0}$ and $\mathrm{Z}_{1}$ represent consumption 0 and 10 ton per hectare, respectively; L.S.: level of significance; * $\mathrm{P}<0.05$; ** $\mathrm{P}<$ 0.01; Non-significant (ns) effect of interaction. 
Table 6 Effects of zeolite and hybrid interaction on yield and quality traits of silage corn.

\begin{tabular}{|c|c|c|c|c|c|c|c|c|}
\hline Zeolite & Hybrid & $\begin{array}{c}\text { Yield } \\
\left(\mathrm{kg} \mathrm{ha}^{-1}\right)\end{array}$ & $\begin{array}{l}\text { CP } \\
(\%)\end{array}$ & $\begin{array}{c}\text { Protein } \\
\text { yield }\end{array}$ & $\begin{array}{c}\text { WSC } \\
(\%)\end{array}$ & $\begin{array}{r}\text { NDF } \\
(\%)\end{array}$ & $\begin{array}{l}\text { ADF } \\
(\%)\end{array}$ & $\begin{array}{c}\text { DMD } \\
\%)\end{array}$ \\
\hline \multirow[t]{3}{*}{$\mathbf{Z}_{0}$} & KSC 704 & $12755^{\mathrm{b}}$ & $9.2^{\mathrm{b}}$ & $1145^{\mathrm{ab}}$ & $30.0^{\mathrm{a}}$ & $44.0^{\mathrm{b}}$ & $26.4^{\mathrm{a}}$ & $66.3^{\mathrm{c}}$ \\
\hline & KSC705 & $9467^{\mathrm{c}}$ & $8.3^{\mathrm{c}}$ & $752^{\mathrm{c}}$ & $25.0^{\mathrm{d}}$ & $39.9^{c}$ & $24.0^{\mathrm{b}}$ & $70.7^{\mathrm{a}}$ \\
\hline & KSC720 & $11384^{\mathrm{b}}$ & $9.9^{\mathrm{a}}$ & $1080^{\mathrm{b}}$ & $28.3^{\mathrm{b}}$ & $43.5^{\mathrm{b}}$ & $25.9^{\mathrm{ab}}$ & $64.5^{\mathrm{c}}$ \\
\hline \multirow[t]{3}{*}{$\mathbf{Z}_{1}$} & KSC 704 & $15904^{\mathrm{a}}$ & $8.2^{\mathrm{c}}$ & $1286^{\mathrm{a}}$ & $28.7^{\mathrm{b}}$ & $45.9^{\mathrm{ab}}$ & $27.0^{\mathrm{a}}$ & $65.2^{\mathrm{c}}$ \\
\hline & KSC705 & $12015^{\mathrm{b}}$ & $7.2^{\mathrm{d}}$ & $850^{\mathrm{c}}$ & $24.9^{\mathrm{d}}$ & $44.0^{\mathrm{b}}$ & $25.1^{\mathrm{ab}}$ & $68.4^{\mathrm{b}}$ \\
\hline & KSC720 & $14398^{\mathrm{a}}$ & $8.9^{\mathrm{b}}$ & $1247^{\mathrm{ab}}$ & $26.4^{\mathrm{c}}$ & $48.6^{\mathrm{ab}}$ & $26.8^{\mathrm{a}}$ & $64.8^{\mathrm{c}}$ \\
\hline L.S. & & ns & ns & ns & Ns & ns & ns & ns \\
\hline
\end{tabular}

Means in the same column followed by letters differ significantly at $\mathrm{P}<0.05 ; \mathrm{Ir}_{70}, \mathrm{Ir}_{100}$, and $\operatorname{Ir}_{130}$ represent high, moderate, and low irrigation levels; $\mathrm{Z}_{0}$ and $\mathrm{Z}_{1}$ represent consumption 0 and 10 ton per hectare, respectively; L.S.: level of significance; $* \mathrm{P}<0.05$; ** $\mathrm{P}<$ 0.01 ; Non-significant (ns) effect of interaction.

While in hybrids KSC704 and KSC720, mild stress increased the WSC content significantly, but in hybrid KSC705 the mild stress did not have significant effect on water-soluble carbohydrates. In combination also, highest WSC content (31.4\%) was observed in the combination of $\operatorname{Ir}_{130}$ and KSC704 hybrid (Table 5).

\subsubsection{Acid detergent fiber \& neutral detergent fiber}

Acid detergent fiber (cellulose and lignin) and neutral detergent fiber (hemicelluloses, cellulose, and lignin) are considered to be two important characteristics of forage quality (Caballero et al., 1995; Assefa \& Ledin, 2001).High quality forages have low concentrations of both NDF and ADF. According to the results of variance analysis, irrigation treatments had a significant effect on ADF and NDF concentrations of forage. Both ADF and NDF follow an incremental trend as interval irrigation increased (Table 3). Newman (2014) reported an association between the improvement of corn plant ADF and NDF content and drought stress. Similarly, Xu \& Lascano (2007) reported that drought stress increased concentrations of both NDF and ADF forage by reducing the share of grain and ear in corn. Contradictory finding was reported by Küchenmeister et al. (2013) when they studied the effect of drought condition on ADF and NDF content of forage legumes; they found that drought stress reduced NDF and ADF concentration for forage legumes.

Further, in this study it was reported that ADF and NDF content was not affected by using zeolite (Table 2) but significant difference was reported in the value of ADF and NDF content in case of tested cultivars $(\mathrm{P}<.05)$. Among various tested cultivars, lowest ADF and NDF content was reported from the KSC705 cultivarand KSC704 and KSC720 cultivars showed superiority over this (Table 6). Also, forage NDF content was influenced by the interaction of irrigation regime and hybrid $(\mathrm{P}<.05)$. The highest NDF content $(54 \%)$ was observed in combination of irrigation treatment $\operatorname{Ir}_{130}$ and KSC720 hybrid while the lowest NDF content was reported from the combination of treatment $\operatorname{Ir}_{100}$ and KSC705 hybrid (36.8\%) (Table 5).

\subsubsection{Dry matter digestibility}

Improving the digestibility of forage is an important objective of breeding programs because high digestibility, improves forage intake and efficiency of conversion of nutrients by livestock. According, Coleman \& Moore (2003) dry matter digestibility represents digestible energy. In this study, forage DMD significantly influenced by irrigation level and hybrid (Table 2). Opposite to ADF and NDF concentrations, forage DMD declined significantly $(\mathrm{P}<0.01)$ as the interval of irrigation increased (Table 3 ). It could be due to increase of ADF concentration at higher interval of irrigation and negative correlation of DMD with $\mathrm{ADF}$ and NDF accumulation. Negative correlation between DMD and hemicelluloses has already been reported by various researcher in several similar studies (Theander \& Westerlund, 1986; Hatfield, 1993; Contreras-Govea et al., 2009). Further, Wilson \& Ng (1975) observed a better water status in maturing plants alleviated the extent of digestibility decrease in senescing leaves and stems. Study also suggested that application of Zeolite had no significant effect on DMD forage (Table 2). Further, hybrids had significant difference $(\mathrm{P}<0.01)$ on DMD content (Table 2 ). The highest DMD concentration $(69.5 \%)$ was recorded for KSC705 (Table 3). It would be due to the lower content of ADF in this hybrid compared with KSC704 and KSC720.

\section{Conclusion}

Results of study revealed a noticeable effect of water deficiency on the production of forage and all three selected cultivars had highest forage production at the $\operatorname{Ir}_{70}$ irrigation regime. Under such experimental conditions, irrigation levels seemed to be a more influential factor compared to zeolite with regards to most forage quality and quantity parameters. Zeolite increased forage and protein yield under different irrigation regimes but it did not showed any significant effect on rest of the studied forage quality parameters. Therefore, considering the water shortage in the country and importance of silage corn as a forage plant, application of zeolite can be useful to save more water that leads to produce more yields. Overall, KSC704 hybrid showed superiority over the rest two hybrids 
due to greater forage dry matter production and higher protein yield. On the other hand, KSC705 produced more desirable forage in terms of some forage quality parameters.

\section{Acknowledgements}

The authors would like to thank respectable authorities on Seed and Plant Improvement Institute in Karaj, as well as Department of Agronomy, Faculty of Agriculture, Islamic Azad University of Karaj, Iran that helped us in carrying out this study.

\section{Abbreviations}

$\operatorname{Ir}_{70} \quad$ - Optimum irrigation Levels (at $70 \mathrm{~mm}$ evoparation)

$\mathrm{Ir}_{100}$ - Moderate irrigation Levels (at $100 \mathrm{~mm}$ evoparation)

$\operatorname{Ir}_{130} \quad$ - Low irrigation Levels (at $130 \mathrm{~mm}$ evoparation)

$\mathrm{CP} \quad$ - Crude protein

WSC - Water soluble carbohydrate

ADF - Acid detergent fiber

NDF - Neutral detergent fiber

DMD - Dry matter digestibility

\section{Conflict of interest}

Authors would hereby like to declare that there is no conflict of interests that could possibly arise.

\section{Reference}

Abarghouei HB, Zarch MAA, Dastorani MT, Kousari MR,Zarch MS (2011) The survey of climatic drought trend in Iran. Stochastic Environmental Research and Risk Assessment 25:851-863. DOI: 10.1007/s00477-011-0491-7.

Ahmed OH, Sumalatha G, NikMuhamad A (2010) Use of zeolite in maize (Zea mays) cultivation on nitrogen, potassium and phosphorus uptake and use efficiency. International Journal of the Physical Sciences 5:2393-2401. DOI: 10.5897/IJPS

Armandpisheh O, Irannejad H, Allahdadi I, Amiri R, Ebadi AG, Koliaei AA (2009) Application of Zeolite in Drought Stress on Vigority of Canola Seed (Zarfam Cultivar). American-Eurasian Journal of Agricultural and Environmental Science 5:832-837.

Asay KH, Jensen KB, Waldron BL, Han G, Monaco TA (2002) Forage quality of tall fescueacross an irrigation gradient. Agronomy Journal 94: 1337-1343. doi:10.2134/agronj2002.1337.

Assefa G, Ledin I (2001) Effect of variety, soil type and fertilizer on the establishment, growth, forage yield, quality and voluntary intake by cattle of oats and vetches cultivated in pure stands and mixtures. Animal Feed Science and
Technology 92:95-111. http://dx.doi.org/10.1016/S03778401(01)00242-5.

Asseng S, Milroy SP (2006) Simulation of environmental and genetic effects on grain protein concentration in wheat. European Journal of Agronomy 25:119128.http://dx.doi.org/10.1016/j.eja.2006.04.005.

Azizi F, Mahrokh A (2012) Effect of drought stress on yield and yield components of sweet corn hybrids. Journal of crop production research (environmental stresses in plant sciences) 3: $351-360$

Bethke PC, Sabba R, Bussan AJ (2009) Tuber water and pressure potentials decrease and sucrose contents increase in response to moderate drought and heat stress. American Journal of Potato Research 86:519-532. DOI: 10.1007/s12230009-9109-8.

Buxton DR (1996) Quality-related characteristics of forages as influenced by plant environment and agronomic factors. Animal Feed Science and Technology 59:37-49. doi:10.1016/0377-8401(95)00885-3.

Caballero R, Goicoechea E, Hernaiz P (1995) Forage yields and quality of common vetch and oat sown at varying seeding ratios and seeding rates of vetch. Field Crops Research 41:135140. doi:10.1016/0378-4290(94)00114-R.

Coleman SW, Moore JE (2003) Feed quality and animal performance. Field Crops Research 84:17-29. http://dx.doi.org/10.1016/S0378-4290(03)00138-2.

Contreras-Govea FE, Muck RE, Armstrong KL, Albrecht KA (2009) Fermentability of corn-lablab bean mixtures from different planting densities. Animal Feed Science and Technology 149:298-306. http://dx.doi.org/10.1016/j.anifeedsci.2008.05.009.

Curran B, Posch J (1999) Agronomic Management of silage for yield and quality (silage cutting height). Crop Insights : 10: 48-57.

DaCosta M, Huang B (2006) Deficit irrigation effects on water use characteristics of bent grass species. Crop science 46:17791786. doi:10.2135/cropsci2006.01-0043.

Dwivedi S, Nigam S, Rao RN, Singh U, Rao K (1996) Effect of drought on oil, fatty acids and protein contents of groundnut (Arachis hypogaea L.) seeds. Field Crops Research 48:125133. doi:10.1016/S0378-4290(96)01027-1.

Eskandari H, Ghanbari A, Javanmard A (2009) Intercropping of cereals and legumes for forage production. Notulae Scientia Biologicae 1:7-13. http://dx.doi.org/10.15835/nsb.1.1.3479. 
Gooding M, Ellis R, Shewry P, Schofield J (2003) Effects of restricted water availability and increased temperature on the grain filling, drying and quality of winter wheat. Journal of Cereal Science 37:295-309. doi:10.1006/jcrs.2002.0501.

Haberle J, Svoboda P, Raimanova I (2008) The effect of postanthesis water supply on grain nitrogen concentration and grain nitrogen yield of winter wheat. Plant Soil Environment 54:304-312

Hesse PR (1971) A Text Book of Soil Chemical Analysis. John Murray Ltd. London, Pp 520.

Hatfield RD (1993) Cell wall polysaccharide interactions and degradability. In Jung HG, Buxton DR, Ralph J (Eds.) Forage cell wall structure and digestibility, American Society of Agronomy, Madison, USA, Pp 297 307.doi:10.2134/1993.foragecellwall.frontmatter

Huang Z, Petrovic A (1994) Physical properties of sand as affected by clinoptilolite zeolite particle size and quantity. Journal of Turf grass Management 1:1-15. http://dx.doi.org/10.1300/J099v01n01_01.

Hussain M, Malik MA, Farooq M, Ashraf MY, Cheema MA (2008) Improving Drought tolerance by exogenous application of glycinebetaine and salicylic acid in sunflower. Journal of agronomy and Crop Science 194 : 193-199. DOI: 10.1111/j.1439-037X.2008.00305.x.

Jahanzad E, Jorat M, Moghadam H, Sadeghpour A, Chaichi MR, Dashtaki M (2013) Response of a new and a commonly grown forage sorghum cultivar to limited irrigation and planting density. Agricultural Water Management117:62-69. http://dx.doi.org/10.1016/j.agwat.2012.11.001

Jafari AA, Connolly V, Frolich A, Walsh EK(2003) A note on estimation of quality in perennial ryegrass by near infrared spectroscopy. Irish Journal of Agricultural and Food Research 42: 293-299.

Kaya MD, Okçub G, Ataka M, Çıkılıc Y, Kolsarıcıa Ö (2006) Seed treatments to overcome salt and drought stress during germination in sunflower (Helianthus annuus L.). European Journal of Agronomy 24: 291-295. http://dx.doi.org/10.1016/j.eja.2005.08.001

Keshavarz L, Farahbakhsh H (2012) Effect of superabsorbent on physio-morphological traits and forage yield of millet (Pennisetum americanum L.) under different irrigation treatments. International Journal of Plant, Animal and Environmental Sciences.2:149-156.

Kojić D, Pajević S, Jovanović-Galović A, Purać J, Pamer E, Škondrić S, Grubor-Lajšić G (2012) Efficacy of natural aluminosilicates in moderating drought effects on the morphological and physiological parameters of maize plants (Zea mays L.). Journal of soil science and plant nutrition12:113-123.

http://dx.doi.org/10.4067/S071895162012000100010

Kramer PJ, Boyer JS (1995) Water relations of plants and soils. Academic Press, New York, Pp 349-374.

Krutilina VS, Polyanskaya SM, Goncharova NA, Letchamo W (2000) Effects of zeolite and phosphogypsum on growth, photosynthesis and uptake of $\mathrm{Sr}, \mathrm{Ca}$ and $\mathrm{Cd}$ by barley and corn seedlings. Journal of Environmental Science \& Health Part A 35 : 15-29. http://dx.doi.org/10.1080/10934520009376952.

Küchenmeister K, Küchenmeister F, Kayser M, WrageMönnig N, Isselstein J (2013) Influence of drought stress on nutritive value of perennial forage legumes. International Journal of Plant Production 7: 693-710.

Marsalis M, Bean B (2010) Nutrient Management. In: Dahlberg J, Roemer E, Casten J, Kilgore G (Eds.) Western forage production guide, Sorghum Check off, Texas, Pp 29-35.

Marsalis MA, Angadi S, Contreras-Govea FE, Kirksey RE (2009) Harvest timing and byproduct addition effects on corn and forage sorghum silage grown under water stress. Bulletin 799, New Mexico State University.http://aces.nmsu.edu/pubs/research/agronomy/BL799.pdf.

Mumpton FA (1999) La rocamagica: uses of natural zeolites in agriculture and industry. Proceedings of the National Academy of Sciences of the United States of America 96:3463-3470. doi: 10.1073/pnas.96.7.3463

Najafinezhad H, TahmasebiSarvestani Z, ModarresSanavy SAM, Naghavi H (2014) Effects of Irrigation Regimes and the Use of Barley Residue, Zeolite and Superabsorbent Polymer on Forage Yield and Water Use Efficiency of Maize and Sorghum in Double Cropping System under Minimum Tillage. Seed and Plant Production Journal30:327-349 (In Persian).

Nakayama N, Saneoka H, Moghaieb R, Premachandra G, Fujita K (2007) Response of growth, photosynthetic gas exchange, translocation of 13C-labelled photosynthate and $\mathrm{N}$ accumulation in two soybean (Glycine max L.) Merrill) cultivars to drought stress. International Journal of Agriculture and Biology 9: 669-674.

Nasri M, Khalatbari M, Paknejad F (2012) Evaluation the effect of different ranges Zeolite consuming on yield and yield component and physiological characteristics of grain Sorghum (Sorghum bicolor L.)VAr. Kimiya under water deficit stress. Annals of Biological Research 3: 3547-3550.

Newman MA (2014) Defining the energy and nutrient content of corn grown in drought-stressed conditions and determining the relationship between energy content of corn and the response of growing pigs to xylanase supplementation. MSc thesis submitted to the Iowa State University, Pp 5-25. 
Nonami H (1998) Plant water relations and control of cell elongation at low water potentials. Journal of Plant Research.111: 373-382. Doi: 10.1007/BF02507801.

Pelleschi S, Rocher JP, Prioul JL (1997) Effect of water restriction on carbohydrate metabolism and photosynthesis in mature maize leaves. Plant, Cell \& Environment 20:493-503. DOI: 10.1046/j.1365-3040.1997.d01-89.x

Pessarakli MM, Morgan P, Gilbert JJ (2005) Dry-matter yield, protein synthesis, starch, and fiber content of barley and wheat plants under two irrigation regimes. Journal of Plant Nutrition 28:1227-1241. DOI: 10.1081/PLN-200063262.

Pirzad A, Mohammadzade S (2014) The effects of drought stress and zeolites on the protein and mineral nutrients of Lathyrus sativus. International Journal of Biosciences 4:241248. doi:10.12692/ijb/4.7.241-248.

Pisarovic A, Filipan T, Tisma S (2003) Application of zeolite based special substrates in agriculture: ecological and economical justification. Periodicum biologorum105:287-293.

Polat E, Karaca M, Demir H, Naci-Onus A (2004) Use of natural zeolite (clinoptilolite) in agriculture. Journal of Fruit and Ornamental Plant Research 12:183-189.

Rostamza M, Chaichi MR, Jahansooz MR, Mashhadi HR, Sharifi HR (2011) Effects of water stress and nitrogen fertilizer on multi-cut forage pearl millet yield, nitrogen, and water use efficiency. Communications in Soil Science and Plant Analysis 42 : 2427-2440. DOI: 10.1080/00103624.2011.609252.

SAS Institute (2003) SAS/STAT User's Guide, Version 9.1. SAS Institute, Cary, NC.

Theander O, Westerlund EA (1986) Studies on dietary fiber. 3. Improved procedures for analysis of dietary fiber. Journal of Agricultural and Food Chemistry 34:330-336. DOI: $10.1021 /$ jf00068a045.
Torkashvand AM, Shadparvar V (2013) Effect of some organic waste and zeolite on water holding capacity and PWP delay of soil. Current Biotica 6:459-465.

Turk M, Bayram G, Budakli E, Celik N (2006) A Study on Effects of Different Mixtures of Zeolite with Soil Rates on Some Yield Parameters of Alfalfa (Medicago sativa L.). Journal of Agronomy. 5:118-121. DOI: 10.3923/ja.2006.118.121

Valadabadi SA, Shiranirad AH, Farahani HA (2010) Ecophysiological influences of zeolite and selenium on water deficit stress tolerance in different rapeseed cultivars. Journal of Ecology and the Natural Environment 2:154-159.

Vasilakoglou I, Dhima K, Karagiannidis N, Gatsis T (2011) Sweet sorghum productivity for biofuels under increased soil salinity and reduced irrigation. Field Crops Research 120:3846. http://dx.doi.org/10.1016/j.fcr.2010.08.011

Wang Y, Frei M (2011) Stressed food-The impact of abiotic environmental stresses on crop quality. Agriculture, Ecosystems \& Environment 141:271-286. http://dx.doi.org/10.1016/j.agee.2011.03.017

Weightman RM, Millar S, Alava J, Foulkes MJ, Fish L, Snape JW (2008) Effects of drought and the presence of the 1BL/1RS translocation on grain vitreosity, hardness and protein content in winter wheat. Journal of Cereal Science 47:457-468. DOI: 10.1016/j.jcs.2007.05.011

Wilson J, Ng T (1975) Influence of water stress on parameters associated with herbage quality of Panicum maximum var. trichoglume. Crop and Pasture Science 26:127136.http://dx.doi.org/10.1071/AR9750127

Xu W, Lascano R (2007) New Stress Tolerant Corn Germplasm for Higher Water Use Efficiency and Water Conservation. The final report of the research project, Texas Water Development Board. Available on http://www.twdb.texas.gov/publications/reports/contracted_rep orts/doc/2005358021_germplasm.pdf accessed on 30 November 2007, Pp 1-10. 